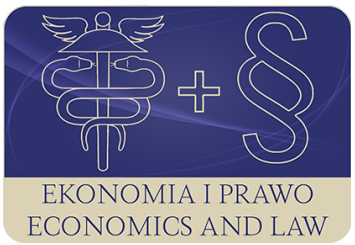

EKONOMIA I PRAWO. ECONOMICS AND LAW

Volume 19, Issue 1, March 2020

p-ISSN 1898-2255, e-ISSN 2392-1625

www.economicsandlaw.pl

EKONOMIA I PRAWO
ECONOMICS AND LAW

ORIGINAL ARTICLE

received 30.03.2019; revised 12.12.2019; accepted 31.03.2020

Citation: Sobocka-Szczapa, H. (2020). Acquiring knowledge workers in organizations. Ekonomia $i$

Prawo. Economics and Law, 19(1): 119-134. doi:10.12775/EiP.2020.009.

\title{
Acquiring knowledge workers in organizations
}

\author{
HALINA SOBOCKA-SZCZAPA \\ Social Academy of Sciences in Łódź, ul. Sienkiewicza 9, 90 -113 Łódź, Poland \\ $\square$ hszczapa@san.edu.pl \\ iD orcid.org/0000-0002-3130-1100
}

\begin{abstract}
Motivation: In modern enterprises, the basic meaning — in connection with the depletion of other capital resources, and especially natural resources - is the knowledge that determines the value of human capital used in organizations. Very often, therefore, we are currently meeting the term economy based on knowledge, which means the ability of the economy to absorb and simultaneously generate processes related to shaping the competencies of human resources. It is extremely important to verify the relationship between the organization and the labor market as a source of knowledge workers acquisition. The importance of knowledge management in contemporary organizations is the result of the appearance of people with such a unique level of knowledge that they usually decide about the success of the organization's activities. They are known as knowledge workers. Acquiring knowledge workers is now a must for all organizations, and their management.
\end{abstract}

Aim: The main objective of the study is to present the category of knowledge workers in the context of knowledge management and the possibility of acquiring such employees by modern organizations. The method used in the study is a study review of the literature and statistical analysis of databases.

Results: The added value of the analysis is the indication of the relationship between the situation on the labor market and the availability of knowledge workers for companies.

Keywords: labor market; ways of acquiring employees; knowledge workers; knowledge management

JEL: Ll; Al 


\section{Introduction}

Due to the depletion of other capital resources, especially natural resources, in contemporary economies, the use of knowledge, which is the value of human capital, is becoming increasingly important. Very often, therefore, we are currently meeting the term economy based on knowledge, which means the ability of the economy to absorb and simultaneously generate processes related to shaping the competencies of human resources. Knowledge is both a product and a driver of the economy, however, it requires a continuous learning process from both the individual and the company, which should also contribute to shaping the skills of knowledge transformation and its effective use (Wronowska, 2004). In some studies, it is explicitly emphasized that the knowledge-based economy is a model of modern economic development (Niklewicz-Pijaczyńska, 2011, p. 444).

The importance of knowledge management in contemporary organizations is the result of the appearance of people with such a unique level of knowledge that they usually decide about the success of the organization's activities. They are known as knowledge workers ${ }^{1}$. It is these employees who are predestined in organizations to create and disseminate knowledge and information (Skrzypek, 2002, p. 679), that is in the knowledge management processes they constitute the main link in the company's success.

Acquiring knowledge workers is now a must for all organizations, and their management - a challenge, because these employees are aware that for the organization they constitute valuable human capital, characterized by a high degree of individualization and uniqueness, which is important especially in the conditions of lack of continuity and constantly progressing changes socio-economic, in which the role of knowledge increases.

The main objective of the study is to present the category of knowledge workers in the context of knowledge management issues and its links with the recruitment process, especially knowledge workers. During the conducted analyzes, an attempt was made to verify the following research hypotheses:

acquiring knowledge workers in organizations is conducted by managers or business owners with methods that do not differ from the methods of acquiring other employees;

the situation on the labor market does not affect the differentiation of ways of acquiring different categories of employees.

\section{Literature review}

In this part of the study, we will look at selected concepts of knowledge workers, knowledge management and methods of acquiring knowledge employees.

\footnotetext{
${ }^{1}$ This formulation was first used by P.F. Drucker (1959).
} 


\subsection{Knowledge workers: an outline of the issues}

Based on the definition of a knowledge worker, formulated by P.F. Drucker, it should be assumed that the most important criterion for distinguishing such an employee is formal education. A similar view is found in M. Morawski's publications (2009, p. 54). In the subject literature, however, we also encounter other definitions, highlighting other features such as the ability to quickly solve problems, technical competence ${ }^{2}$. Also P.F. Drucker in his subsequent works emphasized the importance of the opposites between a manual worker and a knowledge worker. The manual worker uses only manual skills and physical strength at work, while the knowledge worker - what he learned during systematic education, while the simultaneous ability to apply knowledge in practice is necessary (Drucker, 1999, pp. 13-14; Elliman et al., 2005, pp. 79-84). A. Fazlagić (2001) shares this thesis, who states that the knowledge of such employees about their work is basically unlimited and greater than anyone else in the company.

One of the best-known definitions of knowledge workers is that which was formulated by T.H. Davenport (2007, pp. 22-24, 26). He emphasizes the importance of an employee having both a high level of specialist knowledge, education (at least at the undergraduate level) or experience, as well as the presence of a particular type of work, one that would require the creation, distribution and use of knowledge. It follows from this definition, therefore, that the knowledge worker must implement this knowledge while performing work, while creating added value in modern products and technologies ${ }^{3}$. In another way, he treats the knowledge workers M. Armstrong (2007, pp. 166-168). He claims that the basis for recognizing an employee as a knowledge worker is the process of permanent learning.

For N. Beck, the basic criterion for recognizing an employee as a knowledge worker were the positions they occupied (specialists, senior managers, technical and scientific personnel, and engineers) (Stewart, 2001, p. 59). This criterion makes it easier to locate employees in the knowledge in the company, but from the point of view of the organization and its success, this definition seems too narrow, because other groups of positions of key importance from this point of view are ignored.

In the definition of knowledge worker K. Perechuda (2007, pp. 139-140), however, independence, individuality and encouragement to creativity were emphasized. The definition makers from the analytical company Gartner Group are still going, who considered important features of trust, independence, sense of responsibility, adherence to ethical standards as part of decisions made by

2 We have such views in the elaborations of, among others, W.M. Grudzewski and I. Hejduk (2000), T.H. Davenport (2007), N. Beck (Morawski, 2009, p. 43), and M. Morawski (2003, p. 19).

3 The position of M. Morawski (2003), F. Horibe (Fryczyńska, 2003), M. Bratnicki (2000) and E. Skrzypek (2002, p. 679) is similar. 
employees in their respective areas of activity (domains) (Morello \& Caldwell, 2001). In this case, there is a greater loyalty of knowledge workers towards the profession performed than to the employer. The task of the organization is only to create favorable conditions for achieving the goals of individual employees. Knowledge workers have the intuition of how and where to allocate knowledge to use it as effectively as possible (Fazlagić, 2002, p. 33).

The definitions of knowledge workers cited above, due to the relatively large diversity, may affect the limited possibility of making a clear division into knowledge workers and other employees. An additional difficulty is also the fact that currently identified groups of employees are numerous and internally diversified. Therefore, there are also opinions in the subject literature that all members of the organization are knowledge workers. This approach is represented, inter alia, by G. Krough et al. (2000). Being an employee of knowledge results from humanity and is therefore a feature of every employee ${ }^{4}$. Working with knowledge is not a privilege of certain categories of employees, and limiting yourself to a small group of employees may constitute a barrier to organizational development. Knowledge management must therefore be aimed at extracting the ability to create knowledge from all employees (Krough et al., 2000, p. 12). Employees are therefore the carriers of capital rather than labor (Drucker, 2002, p. 76), while the productivity of this capital and return on investment join the group of the most important problems facing human resources management and knowledge management, which is a consequence of treating employees especially knowledge, as an asset that must be increased, not a source of costs (Drucker, 2009, p. 153).

\subsection{Knowledge management in the organization}

Knowledge management - this is a special case of management in general, the most important element of which is working with people (Griffin, 1998, p. 38) $)^{5}$. Knowledge management, focused on specific people's characteristics, which are their knowledge and experience. These features are reflected in many definitions of knowledge management (Gladstone, 2004, p. 88; Griffin, 1998).

The literature on the subject distinguishes many concepts of the knowledge management process. The simplest of them focus only on three processes: acquisition (creation) of knowledge, its dissemination (sharing of knowledge) and use (Morawski, 2005, p. 80; Sarvay, 1999, p. 96). A. Jashapara (2006) proposes a full cycle of knowledge management based on five processes (using knowledge, disseminating knowledge, discovering knowledge, generating knowledge and valuing knowledge). The most extensive concepts also include

${ }^{4}$ In Polish-language literature, M. Morawski (2009, pp. 40-42), T.H. Davenport (2007, pp. 22-24) met with this kind of assumption, and this assumption became the basis of the author's own analyzes (Sobocka-Szczapa, 2014b, p. 14).

${ }^{5}$ H. Sobocka-Szczapa (2014b) wrote more on knowledge management in the context of human resources management. 
processes such as locating knowledge, archiving knowledge, protecting knowledge and selling $i^{6}{ }^{6}$. The subject literature also meets concepts that take into account the strategic and process aspects of knowledge management (Gladstone, 2004, p. 89). They draw attention to which knowledge-based abilities and resources are valuable, unique and inexistent, as well as where they are located, how these capabilities can and should support the company's market position, its competitiveness and how to acquire them and used to implement the company's development strategy (Gladstone, 2004, p. 96). In this context, decisions made in knowledge management processes should lead to some choices, eg is it better to acquire knowledge from the outside, store it and use it to achieve specific goals, or maybe it would be better to produce knowledge on its own and export or store with perspective subsequent use. These are very important decisions that lead to the elimination of activities that do not create added value (Sobocka-Szczapa, 2014b, p. 121). This approach therefore has the most important relationship with the processes of acquiring knowledge workers carried out in organizations. Therefore, the main premise of employing knowledge workers and selecting the source of their acquisition is the strategy and potential developed by the organization, enabling the creation and transfer of knowledge.

\subsection{Recruitment of knowledge workers}

The knowledge worker, possessing the ability to use knowledge, can exert a significant influence on a particular organization in given circumstances (bring high value) (Kowalski, 2011, p. 316). Their feature must therefore be employability, that is, having attributes that determine their employment, having a job (Gableta, 2003, p. 133).

Recruitment of knowledge workers is the effect of the work monitoring carried out by the company, employment planning as well as the company's business strategy. In particular, the starting point for properly selected employee selection should be the updating of staffing needs, a detailed analysis of workstations in terms of qualifications and skills of employees employed on them, and consistent activities, enabling their social and professional adaptation. The selection of employees should contribute to the maximum integration and involvement of employees in the tasks carried out by the company (Guest, 1987, pp. 503-521). Recognition of staffing needs may be a guarantee of achieving the goals of an economic entity, as well as affect the increase of its competitiveness ${ }^{7}$. It should also be emphasized in this case the importance of implementing such activities based on the concept of personnel (personnel) marketing, in which the search for appropriate employees should be treated as sales of specific goods, services - 'workplaces' (Jasińska, 2009, p. 88). Inde-

${ }^{6}$ M. Morawski (2005, p. 80), W Kotarba (2006, p. 88 et seq.) and W.R. Bukowitz and R.L. Williams (2000) wrote more on this topic.

7 More on this subject can be found in the publications of P. Filip (2005, pp. 341-350) and T. Kawka and T. Listwan (2009, p. 101 et seq.). 
pendent and creative employee with unique qualifications and high aspirations) is the most important resource not only of the company, but also its basic client (Sobocka-Szczapa, 2014a, p. 105).

Selection of employees requires employers to formulate clear criteria that allow verification of applications submitted by candidates for work. Four types of assessment criteria are usually distinguished: eligibility criteria, effectiveness criteria, behavioral criteria and personality criteria (Staniewski, 2010, p. 83). In the case of knowledge workers, the most important are the qualification criteria. In this case, the competency gaps that are possible in this case constitute the first and most important information for the employer about the needs related to the improvement of the employee and adapting his skills to the position for which he is recruited. Of the other criteria, personality criteria are also important, demonstrating the possibilities of transferring and disseminating knowledge by an employee.

Acquiring knowledge workers is a process consisting of two interdependent activities, namely recruitment and selection, the effect of which is employment of the job applicant (Janowska, 2010, p. 70).

Recruitment is defined in various ways. According to G. Maniak (2001, p. 76), there is a process in which the company encourages people properly educated for a specific position to work in their company and make them report to it. According to A. Szałkowski (2006, pp. 79-80), recruitment is primarily the acquisition by the organization of talented, motivated, healthy and knowledgeable employees. M. Adamiec and B. Kożusznik (2000, pp. 105-106) also emphasize that the need to employ new employees is forced by the need to achieve the company's goal and vision, as well as the need to shape the human resources of the organization. Whereas the recruitment according to A. Pocztowski (1998, p. 134) has a twofold significance: a wider one - the whole process of acquiring people providing work for the organization and a narrower one - the process of attracting candidates to work and then selecting them (Marek, 2008, p. 71). However, for the purposes of this study, the definition of T. Listwan seems to be important, as it recognizes recruitment as a comprehensive process, including activities of seeking, informing and attracting candidates for a specific position (Kawka\& Listwan, 2009, p. 101 et seq.). In this approach, the recruitment concerns primarily the establishment of sources and forms of recruitment.

In practice, many types of recruitment are distinguished ${ }^{8}$. To acquire a knowledge worker, the breakdown is particularly important because of the recruitment source. The selection of the recruitment source depends mainly on the financial resources and time allocated to recruit staff, the development phase of the organization, the situation on the labor market, the applied staff management model and the type of position intended for the cast (Drozdowski, 2012, p. 216).

8 He writes about general and segment recruitment, among others J. Moczydłowska (2010, p. 57) and A. Ludwiczyński (2006, pp. 198-199, 203). The last author also proposed a division of recruitment due to the source of recruitment. 
In the case of searching for knowledge workers in the external market, i.e. the labor market, job offers are made available only in the organization's environment. External recruitment has both many advantages and disadvantages (Szaban, 2011, p. 103). Their knowledge allows to increase the efficiency and effectiveness of this process (Ludwiczyński, 2006, p. 207), and - in order to avoid mistakes - requires its preparation and preparation to attract the right candidates. the 'improper' employee's custody, who fails expectations, leaves work or has to be dismissed - it is a big cost associated with his additional training and insufficient work performance (Griffin, 2004, p. 452). With this in mind, recruitment should fulfill three basic functions: information, motivation and initial selection (Jasińska, 2009, p. 88; Ludwiczyński, 2006, p. 198). The most important function is information, because it must help in making decisions about applying for a job in the position offered (Kalinowski, 2004, p. 126).

\subsection{Methods of searching for knowledge workers}

The external labor market and recruitment conducted on it uses a variety o methods to search for knowledge workers. These include: advertisements in the press, on websites or the Internet, job agencies (Moczydłowska, 2010, p. 57), labor offices, employment offices, job fairs, professional practices and, for example, open days, organized by the company. Such recruitment also requires a wide information campaign ${ }^{9}$. In external recruitment processes, the method is often used, based on the recommendations of trusted people. This method was until recently regarded as a manifestation of protection, which is why it was rarely used. Currently, due to the change of the employment model - which directly results from the situation on the labor market - this way of recruitment has become popular.

However, the most frequently used method of external recruitment is direct search for a job candidate. Choosing the best candidate for the offered position, however, is very laborious in this case. Therefore, always take into account the industry, financial and organizational situation of the company. The greatest advantage of this method is the delicacy and confidentiality of proceedings, as well as narrowing the circle of candidates to a minimum.

Internal recruitment, based on using the human resources of the company (promotion, degradation, staff reserve, internal competition) is a much easier process, because it applies to employees of well-known managers (recognition of competences and competence gaps). It is also less expensive. Internal recruitment is more beneficial for the company because it reduces staff's liquidity and enables quick implementation of employees to the duties provided for in the new workplace.

9 This is called active indirect recruitment method (Wojewódzki Urząd Pracy w Warszawie, 2016, p. 3). 


\section{Methods}

The method used in the study consists of a review of research, literature and statistical analysis of databases related to the Polish labor market. It also made a critical review of the literature in the theoretical context, also analyzing changes in the selected category of concepts. The selection of sources for analysis was subordinated to the purpose of the study. The subject of the analysis are scientific works (individual and collective), which were created in academic centers and other institutions that maintain scientific standards and articles in professional journals of various scope. Foreign-language literature as well as materials from websites were also used in the study. The analysis was carried out in two stages, involving the formulation and justification of the purpose as well as the research hypothesis and highlighting the basic conceptual categories and establishing their definitions in force in the research procedure. Finally, interpretation of the content of individual sources, in line with the objectives and research problem, was undertaken.

\section{Results}

\subsection{Acquiring knowledge workers and the situation on the labor market}

The external recruitment of employees at the moment is facing ever greater barriers, because there are fewer and fewer jobseekers. The labor market is becoming more and more the employee's market, not the employer.

When analyzing the statistical data concerning the labor market in Poland, enabling the assessment of the situation of people with higher education, the following criteria were adopted in terms of acquiring knowledge workers:

- comparability of statistical data was ensured by the selection of data published by the Central Statistical Office in the Statistical Yearbooks of Labor from 2012-2017;

- for the purpose of analysis, the dynamics of changes in the total number of unemployed and jobseekers with higher education was used, as well as the share of the latter in the general population of the unemployed.

This type of analysis may indicate the correctness of recruitment activities carried out by organizations. As results from the conducted research, the trends of changes in the number of unemployed with higher education have always had lower dynamics in the analyzed years in comparison to changes in the total number of unemployed (table 1 ).

This may indicate a significantly worse competitiveness of these people in comparison with other categories of the unemployed. From the point of view of acquiring knowledge workers by enterprises, this is a situation indicating the lack of employability of these labor resources, which may be due to the lack 
of adequacy of competences to the expectations of employers. Therefore, it can be concluded that the methods of external recruitment of knowledge workers are ineffective compared to other groups of wanted employees, especially if we - as defined by P.F. Drucker - are considered to be the only people with the highest qualifications.

Confirmation of this conclusion can also be found by analyzing the share of unemployed people with higher education in the general population of jobseekers. This share in the analyzed period was constantly growing and at the end of the research period it amounted to over $13 \%$. This is particularly dangerous in conditions of permanently improving situation on the labor market. In the analyzed years, the unemployment rate decreased by 4.2 points percent, which with the growing share of the unemployed in higher education means the loss of the most important production potential at present.

\subsection{Analysis of previous studies}

The methods of recruiting employees, including knowledge workers, have been the subject of many studies so far. We will quote only some of them.

In the case of surveys conducted among 100 HR specialists in 2011-2012 at the Higher School of Promotion in Warsaw (Grzegorczyk, 2012), the majority of respondents chose external recruitment sources (82\%). The most commonly used methods of this recruitment included: press advertisements $(61 \% \mathrm{com}$ panies used them sometimes and $21 \%$ companies always), ads on the website (37\% and $49 \%$ respectively), using the services of personal consulting agencies (59\% and $10 \%$ respectively), temporary work agencies (respectively $35 \%$ and $8 \%$ ), labor offices (respectively $40 \%$ and $9 \%$ ) and career offices of universities and schools (54\% and 7\% respectively). In addition, the employees were also recruited in a direct way (it was always done in this way by $12 \%$ of respondents, and sometimes - over $70 \%$ ). Respondents also pointed to recommendations from friends (they were always used by $22 \%$ of respondents, $67 \%$ - sometimes). People who are not qualified are not employed, but qualified employees whose abilities are reflected in the recommendations of others (Jamka, 2007, p. 44).

Taking into account the recruitment of employees for the most responsible positions in the company (board member/director, manager, specialist), i.e. positions on which knowledge workers can be employed - it was, however, more often used internal recruitment (promotion, internal advertisement). Only in relation to the specialist, the largest share was given to responses indicating the use in recruitment of employees from social networks (51\%). The results of these studies indicate, therefore, that for companies, the employees of knowledge are first of all the staff of experienced, 'old' employees who know the company, its specificity and associate it with its career path. This confirms the reluctance to acquire knowledge workers from the labor market, which was previously signaled, analyzing the situation of unemployed with higher education. 
On the other hand, another study conducted in $2013^{10}$ shows that, however, companies are increasingly switching to modern, active forms of recruitment (adverts on websites and websites), with social media portals much less popular ( $9 \%$ of respondents). ). Also to a small extent, the help of advisors did not exceed $10 \%$ of indications, job fairs (6\%) and data banks (7\%). The vast majority of Polish companies recruited independently (93\%).

Research on the acquisition of employees in organizations was also one of the elements of projects carried out by the Institute of Labor and Social Affairs ${ }^{11}$. According to these studies, employees were most often searched through recommendations of relatives and acquaintances (almost half of the answers) and through employment offices ( $42.8 \%$ of responses). In addition, in general, employers themselves verified the suitability of employees in recruitment processes. However, the external recruitment concerned only the lower level employees. Knowledge workers in the sense of P.F. Drucker were not recruited at all (Kukulak-Dolata \& Sobocka-Szczapa, 2013, p. 69; Samoraj-Charitonow \& Mirosław, 2011, pp. 293-294). The conducted research has also resulted in the relationship between the recruitment method and their age (Sobocka-Szczapa, 2013, p. 114). This means that it is inefficient to use recruitment methods that are unknown or not available to a specific population of potential employees.

\section{Conclusions}

The objective need of today's enterprises is to seek the employment of above all qualified and competent employees, who are expected to participate in creating the value of an organization that is the basis for building its competitive advantage. This is, therefore, an obvious proof that in the activities of enterprises, it is increasingly necessary to increase the importance of correctly recruiting employees, especially knowledge workers. This is particularly important in the case of intellectual capital management, and this is the knowledge workers (Kociatkiewicz \& Kostera, 2013).

The problem of acquiring knowledge workers is also a consequence of the knowledge management process in the organization, as recruitment from

${ }^{10}$ Data from the survey conducted by eSelektio.com (2013) in cooperation with the Department of Trade and Marketing of the University of Economics in Poznań as part of the Innovative Economy: National Cohesion Strategy program, co-financed from the European Regional Development Fund.

${ }^{11}$ Project Wykluczenie cyfrowe na Mazowszu, implemented in 2011 as part of the Human Capital Operational Program, priority VII: promotion of social integration, measure 7.2.: counteracting exclusion and strengthening the social economic sector, sub-measure 7.2.1: professional and social activation of people at risk of social exclusion; Project Badanie wptywu elastycznych form zatrudnienia i organizacji pracy na aktywność zawodowa zasobów pracy $w$ wieku 45+, implemented in 2013; Project Analiza procesów zachodzących na polskim rynku pracy i $w$ obszarze integracji spotecznej $w$ kontekście prowadzonej polityki gospodarczej, task 2: development of an integrated forecasting and information system enabling employment forecasting, implemented in the years 2011-2014. 
the internal market is usually applied to such employees. However, it should be emphasized that the study cited in the study does not fully take into account the division into knowledge of employees in the strict sense and other employees. Therefore, this problem should be applied to all employees, treating them as employees of knowledge. Therefore, it can be concluded that the methods of recruitment are not differentiated due to the type of employee, although a somewhat greater tendency of employers to recruit employees to lower positions from the external market is noticeable. Therefore, it can be assumed that the assumption contained in the first hypothesis should rather be rejected. In this case, the proper management of knowledge in the organization is of greater importance, especially in the context of knowledge sharing ${ }^{12}$, which is particularly important in the situation of changing the status of the employee as a result of internal recruitment. It is therefore necessary to develop such a model of interpersonal contacts as well as the flow of information so that knowledge workers - while maintaining their status quo — are characterized by a high inclination to support other employees - and thus the organization - with their knowledge.

There is another situation with the second hypothesis. This principle should be rather agreed, because this kind of relationship was not observed. However, it is important in this case to determine the necessity of such changes. The improving situation on the labor market should contribute to increased interest in these methods, which will contribute to greater coherence of the candidate's competences to work with the job position offered by the employer. Therefore, it would be necessary to use more active methods of acquiring employees, which should include: using the services of personal consulting agencies, temporary work and career offices. Therefore, the recruitment process should open to external institutions and organized events, which — in a professional and wider way - can increase access to numerous staff of both specialists and regular employees. Staying with the existing methods will undoubtedly increase the employment difficulties of the organization.

The lowest unemployment rate in Poland, which is one of a quarter of a century, causing difficulties in recruiting employees, requires more from employers. Companies must be aware that if they want to create a strong team, they must not only invest in it, but above all, reach those people who can be a valuable asset for the company. It is therefore necessary to modify the recruitment processes and methods used in this process. In perspective - this will allow to create a loyal team of motivated experts whose engagement will positively influence the development of the organization. It is also necessary to look for solutions that enable the education market to be modified in terms of the needs of employers. This is because the organization is more interested in the resources of knowledge and experience possessed by the employee than the employee

12 Such action is not in human nature. E. Krok (2007, pp. 93-94) wrote about other barriers. 
himself, who does not need a specific employer to accomplish his professional goals (Stosik, 2005, pp. 204-207).

\section{References}

Adamiec, M., \& Kożusznik, B. (2000). Zarządzanie zasobami ludzkimi: aktor, kreator, inspirator. Kraków: Akade.

Armstrong, M. (2007). Zarządzanie zasobami ludzkimi. Kraków: Wolters Kluwer Business.

Bratnicki, M. (2000). Podstawy wspótczesnego myślenia o zarządzaniu. Dąbrowa Górnicza: WSB.

Bukowitz, W.R., \& Williams, R.L. (2000). The knowledge management fieldbook. London: Financial Times/Prentice Hall.

Central Statistical Office. (2014). Yearbook of labour statistics 2012. Retrieved 29.11.2019 from https://stat.gov.pl.

Central Statistical Office. (2016). Yearbook of labour statistics 2015. Retrieved 29.11.2019 from https://stat.gov.pl.

Central Statistical Office. (2018). Yearbook of labour statistics 2017. Retrieved 29.11.2019 from https://stat.gov.pl.

Davenport, T.H. (2007). Zarządzanie pracownikami wiedzy. Kraków: Wolters Kluwer Polska.

Drozdowski, G. (2012). Kształtowanie zatrudnienia w organizacjach publicznych. Studia Lubuskie, 8.

Drucker, P.F. (1959). Landmarks of tomorrow. New York: Harper.

Drucker, P.F. (1999). Spoteczeństwo pokapitalistyczne. Warszawa: PWN.

Drucker, P.F. (2002). They're not employees, they're people. Harvard Business Review, 80(2).

Drucker, P.F. (2009). Zarządzanie XXI wieku: wyzwania. Warszawa: MT Biznes.

Elliman, T., Eatock, T., \& Spencer, N. (2005). Modelling knowledge worker behawior in business proces studies. Journal of Enterprise Information Management, 18(1). doi:10.1108/17410390510571501.

eSelektio.com. (2013). Badanie procesów rekrutacji 2013. Retrieved 29.11.2019 from http://www.outsourcingportal.eu.

Fazlagić, A. (2001). Zatrudnianie i produktywność w gospodarce wiedzy. Problemy Jakości, 33(11).

Fazlagić, J.A. (2002). Szkoła jako instytucja ucząca się. In B.D. Gołębniak (Ed.), Uczenie metoda projektów. Warszawa: WSiP.

Filip, P. (2005). Rozwój przedsiębiorstwa przy uwzględnieniu doboru kadr. Nierówności spoteczne a wzrost gospodarczy, 7(2).

Fryczyńska, M. (2003). Pracownicy wiedzy: nowe wyzwanie zarządzania organizacjami. Zarządzanie Zasobami Ludzkimi, 1.

Gableta, M. (2003). Cztowiek i praca w zmieniającym się przedsiębiorstwie. Wrocław: AE we Wrocławiu. 
Gladstone, B. (2004). Zarządzanie wiedzą. Knowledge management. Warszawa: Petit.

Griffin, R.W. (1998). Podstawy zarządzania organizacjami. Warszawa: PWN.

Griffin, R.W. (2004). Podstawy zarządzania organizacjami. Warszawa: PWN.

Grudzewski, W.M., \& Hejduk, I. (2000). Zarządzanie technologiczne wyzwaniem XXI wieku. Przegląd Organizacji, 11.

Grzegorczyk, A. (2012). Subiektywne uwarunkowania procesu doboru personelu w zarządzaniu zasobami ludzkimi: raport badawczy. Retrieved 29.11.2019 from https://depot.ceon.pl.

Guest, D.E. (1987). Human resource management and industrial relations. Journal of Management Studies, 24(5). doi:10.1111/j.1467-6486.1987.tb00460.x.

Jamka, B. (2007). Kierowanie kadrami: pozyskiwanie i rozwój pracowników. Warszawa: Oficyna Wydawnicza SGH.

Janowska, Z. (2010). Zarządzanie zasobami ludzkimi. Warszawa: PWE.

Jashapara, A. (2006). Zarządzanie wiedzą: zintegrowane podejście. Warszawa: PWE.

Jasińska, J. (2009). Planowanie kadr. In T. Listwan (Ed.), Zarządzanie kadrami. Warszawa: C.H. Beck.

Kalinowski, M. (2004). Rekrutacja kandydatów do pracy. In W. Golnau, M. Kalinowski, \& J. Litwin (Eds.), Zarządzanie zasobami ludzkimi. Warszawa: CeDeWu.

Kawka, T., \& Listwan, T. (2009). Dobór pracowników. In T. Listwan (Ed.), Zarządzanie kadrami. Warszawa: C.H. Beck.

Kociatkiewicz, J., \& Kostera, M. (2013). Zarządzanie humanistyczne: zarys programu. Problemy Zarządzania, 11(44). doi:10.7172/1644-9584.44.1.

Kotarba, W. (2006). Istota i zakres ochrony wiedzy. In W. Kotarba (Ed.), Ochrona wiedzy a kapitat intelektualny organizacji. Warszawa: PWE.

Kowalski, T. (2011). Pojęcie i cechy pracownika wiedzy. Studia Lubuskie, 7.

Krok, E. (2007). Kluczowe aspekty zarządzania wiedzą. Studia i Materiaty Polskiego Stowarzyszenia Zarządzania Wiedzą, 8.

Krough, G., Ichijo, K., \& Nonaka, I. (2000). Enabling knowledge creation: how to unlock the mystery of tacit knowledge and release the power of innovation. Oxford: Oxford University Press.

Kukulak-Dolata, I., \& Sobocka-Szczapa, H. (2013). Synteza wyników badania mikropodmiotów w Polsce. Warszawa: IPiSS.

Ludwiczyński, A. (2006). Alokacja zasobów ludzkich organizacji. In H. Król, \& A. Ludwiczyński (Eds.), Zarządzanie zasobami ludzkimi: tworzenie kapitatu ludzkiego. Warszawa: PWN.

Maniak, G. (2001). Wprowadzenie do zarządzania zasobami ludzkimi. Szczecin: Zachodniopomorska Szkoła Biznesu.

Marek, J. (2008). Pozyskiwanie i dobór personelu: ksztattowanie zatrudnienia w organizacji. Warszawa: Difin.

Moczydłowska, J. (2010). Zarządzanie zasobami ludzkimi w organizacji: podręcznik akademicki. Warszawa: Difin. 
Morawski, M. (2003). Problematyka zarządzania pracownikami wiedzy. Przegląd Organizacji, 1.

Morawski, M. (2005). Ilościowe zarządzanie wiedzą: podejście zachodnie. In K. Perechuda (Ed.), Zarządzanie wiedza w przedsiębiorstwie. Warszawa: PWN.

Morawski, M. (2009). Zarządzanie profesjonalistami. Warszawa: PWE.

Morello, D., \& Caldwell, F. (2001). What are knowledge workers? What makes them thick? Gartner Group Research Note, SPA-12-7780.

Niklewicz-Pijaczyńska, M. (2011). Od koncepcji gospodarki opartej na wiedzy do nowej strategii rozwoju UE 2020. In J. Kundera (Ed.), Globalizacja, europejska integracja a kryzys gospodarczy. Wrocław: Uniwersytet Wrocławski.

Perechuda, K. (2007). Dyfuzja wiedzy w przedsiębiorstwie sieciowym: wizualizacja i kompozycja. Wrocław: AE we Wrocławiu.

Pocztowski, A. (1998). Zarządzanie zasobami ludzkimi: zarys problematyki i metod. Kraków: Antykwa.

Samoraj-Charitonow, B., \& Mirosław, J. (2011). Popytowa strona rynku pracy wobec problemów ksztaltowania społeczeństwa informacyjnego. In H. Sobocka-Szczapa (Ed.), Wykluczenie cyfrowe na Mazowszu: wyniki badań. Retrieved 29.11.2019 from https://www.efs.2007-2013.gov.pl.

Sarvay, M. (1999). Knowledge management and competition in the consulting industry. California Management Review, 41(2). doi:10.2307/41165988.

Skrzypek, E. (2002). Miejsce zarządzania informacją i wiedzą w strategii przedsiębiorstwa. In A. Stabryła (Ed.), Zarządzanie firmą w spoteczeństwie informacyjnym. Kraków: EJB.

Sobocka-Szczapa, H. (2013). Determinaty aktywności zawodowej osób w wieku 45 lat i więcej: opinie pracujących. In E. Kryńska (Ed.), Elastyczne formy zatrudnienia i organizacji pracy a aktywność zawodowa osób starszych. Warszawa: IPiSS.

Sobocka-Szczapa, H. (2014a). Dobór pracowników: decyzja strategiczna firmy. Organizacja i Zarządzanie, 68.

Sobocka-Szczapa, H. (2014b). Zarządzanie pracownikami wiedzy w procesach lifelong learning. Łódź: SAN.

Staniewski, A. (2010). Innowacyjność w zarządzaniu zasobami ludzkimi. In R. Nowacki (Ed.), Innowacyjność w zarządzaniu a konkurencyjność przedsiębiorstwa. Warszawa: Difin.

Stewart, T.A. (2001). The wealth of knowledge: intellectual capital and the twenty-first century organization. London: Nicholas Brealey Publishing.

Stosik, A. (2005). Zarządzanie wiedzą i kapitałem intelektualnym w małych firmach. In K. Perechuda (Ed.), Zarządzanie wiedzą w przedsiębiorstwie. Warszawa: PWN.

Szaban, J.M. (2011). Zarządzanie zasobami ludzkimi w biznesie i administracji publicznej: rynek pracy, dobór, ocena, rozwój i kariera, odejścia z pracy. Warszawa: Difin.

Szałkowski, A. (2006). Podstawy zarządzania personelem. Kraków: AE w Krakowie. 
Wojewódzki Urząd Pracy w Warszawie. (2016). Selekcja i rekrutacja: przegląd stosowanych metod i narzędzi. Retrieved 29.11.2019 from https: / wupwarszawa. praca.gov.pl.

Wronowska, G. (2004). Gospodarka oparta na wiedzy jako etap ewolucji współczesnej gospodarki. In A. Manikowski, \& A. Psyk (Eds.), Unifikacja gospodarek europejskich: szanse i zagrożenia. Warszawa: Uniwersytet Warszawski.

\section{Acknowledgements}

Author contributions: author has given an approval to the final version of the article.

Funding: this research was undertaken as part of the Wykluczenie cyfrowe na Mazowszu project, which was fully funded by resources of the European Social Fund under the Human Capital Operational Program; Badanie wptywu elastycznych form zatrudnienia i organizacji pracy na aktywność zawodowa zasobów pracy w wieku 45+ project, which was fully funded under the long-term research program of the Central Institute for Labor Protection for 20112013 from the funds of the National Center for Research and Development; Opracowanie zintegrowanego systemu prognostyczno-informacyjnego umożliwiającego prognozowanie zatrudnienia project, which was fully funded by resources of the European Social Fund. The publication was financed from the Academy of Sciences in Eódź statutory sources.

Note: the results of this study were presented at 10th International Conference on Applied Economics Contemporary Issues in Economy (June 27-28, 2019, Torun, Poland). 


\section{Appendix}

Table 1.

Unemployed people in total and with higher education in 2010-2016

\begin{tabular}{|c|c|c|c|c|c|}
\hline \multirow[b]{2}{*}{ Year } & \multicolumn{2}{|c|}{ Unemployed in total } & \multicolumn{2}{|c|}{ Unemployed with higher education } & \multirow[b]{2}{*}{$\begin{array}{l}\text { Share } \\
\text { of the unemployed } \\
\text { with higher education } \\
\text { in the total number } \\
\text { of unemployed (in \%) }\end{array}$} \\
\hline & $\begin{array}{l}\text { total number } \\
\text { of unemployed } \\
\text { (in thousands) }\end{array}$ & $\begin{array}{l}\text { indicators } \\
\text { of dynamics } \\
\text { (compared } \\
\text { to the previous } \\
\text { year in \%) }\end{array}$ & $\begin{array}{c}\text { number } \\
\text { of unemployed } \\
\text { with higher } \\
\text { education } \\
\text { (in thousands) }\end{array}$ & $\begin{array}{l}\text { indicators } \\
\text { of dynamics } \\
\text { (compared } \\
\text { to the previous } \\
\text { year in \%) }\end{array}$ & \\
\hline 2010 & 1954.7 & - & 204.7 & - & 10.5 \\
\hline 2011 & 1982.7 & 101.4 & 225.8 & 110.3 & 11.4 \\
\hline 2012 & 2136.8 & 107.8 & 251.0 & 111.2 & 11.7 \\
\hline 2013 & 2157.9 & 101.0 & 258.8 & 103.1 & 12.0 \\
\hline 2014 & 1825.2 & 84.6 & 225.4 & 87.1 & 12.4 \\
\hline 2015 & 1536.2 & 84.2 & 200.2 & 88.1 & 13.0 \\
\hline 2016 & 1335.2 & 86.9 & 177.6 & 88.7 & 13.3 \\
\hline
\end{tabular}

Source: Central Statistical Office (2014, 2016, 2018). 